\title{
Pruning intensity on blackberry phenology and production
}

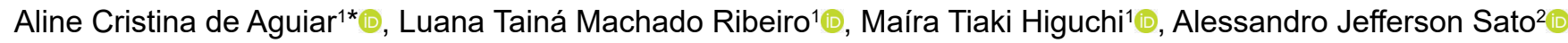 \\ 1 Universidade Estadual de Londrina, Londrina, PR, Brasil. E-mail: aguiar.alinec@gmail.com; luuanataina@hotmail.com; maira.tiaki@gmail.com \\ ${ }^{2}$ Universidade Federal do Paraná, Palotina, PR, Brasil..E-mail: asato@ufpr.br
}

ABSTRACT: The study aimed to evaluate the effect of pruning intensity on the phenology and production of blackberry cV. Xavante. The experiment was carried out at the Federal University of Paraná - Palotina, PR, Brazil, during the 2018/2019 season. The completely randomized design was used as a statical model with four treatments and seven replications. The treatments consisted of different number of stems of $1 \mathrm{~m}$ height retained per bush after the pruning: 2, 4, 6 , and 8 , and each plot consisted of one bush. Data collection included: sprouting and flowering (\%), number of fruits per bush, fresh weight, total soluble solids content and titratable acidity of fruits. The number of stems per bush significantly influenced the number of shoots, flowers and fruits per bush, titratable acidity, soluble solids and maturation index. Under the growth conditions, the treatments consisted of 2 and 4 stems per bush resulted in more uniform growth development and higher chemical quality of fruits. However, the highest number of fruits per bush was observed when 8 stems per bush were retained.

Key words: agricultural practices; number of stems; Rubus spp.

\section{Intensidade de poda na fenologia e produção da amoreira-preta}

RESUMO: O trabalho objetivou avaliar o efeito da intensidade de poda na fenologia e na produção da amoreira-preta cV. Xavante. O experimento foi conduzido durante a safra de 2018/2019 na Universidade Federal do Paraná, Palotina, PR, Brasil. $O$ delineamento experimental utilizado foi inteiramente casualizado, constituindo-se em quatro tratamentos com sete repetições. Os tratamentos consistiram na quantidade de hastes de $1 \mathrm{~m}$ de comprimento deixadas por planta após a poda: 2, 4, 6 e 8 hastes, sendo cada parcela composta por uma planta. As variáveis avaliadas foram: brotação e florescimento (\%), número de frutas por planta, massa fresca, teor de sólidos solúveis e acidez titulável das frutas. 0 número de hastes por planta influenciou significativamente o número de brotos, flores e frutas por planta, acidez titulável, sólidos solúveis e índice de maturação. Nas condições de cultivo, os tratamentos com 2 e 4 hastes resultaram em desenvolvimento vegetativo mais uniforme e frutas com melhor qualidade química, entretanto, o tratamento com 8 hastes resultou no maior número de frutas por planta.

Palavras-chave: tratos culturais; número de ramos; Rubus spp. 


\section{Introduction}

Among the various options of fruit species with good prospects for production and commercialization in Brazil is the blackberry (Rubus spp.), which belongs to the family Rosaceae and the group of "small fruits" (Vignolo et al., 2014). This species is easy to implement and maintain, as well as low use of pesticides, proving to be an excellent cultivation option for family farming or for income diversification, and has great productive potential for the state of Paraná, Brazil (Croge et al., 2016).

Blackberry cultivations in Brazil began through the genetic improvement program of Embrapa Clima Temperado, with cultivars with thorns on the stems and leaves, which made it difficult to manage the crop (Figueiredo et al., 2013). In 2004, as a result of a partnership between Embrapa Clima Temperado and the University of Arkansas (USA), the blackberry 'Xavante' was released, the first thornless blackberry in the country, which provides the producer with greater ease in performing cultural practices (Antunes et al., 2014). The blackberry 'Xavante' is very productive, its stems are vigorous and erect, and it does not require much cold to exit dormancy, about 200 to 300 hours of cold (Brugnara, 2016). Flowering starts in September and may extend until January in the southern hemisphere, and its maturation occurs early, starting the harvest in mid-November and extending until mid-March, depending on the climatic conditions of the year (Lugaresi et al., 2020).

Because they are plants that produce on year branches, which are eliminated after harvest (Strik, 2018), pruning becomes a major cultural management. According to Marchi et al. (2015), the goal of this management is to regulate plant vigor in search of satisfactory and good quality production. This practice is carried out in two moments, in summer, eliminating the stems that have produced and shortening the new stems emerging from the soil, and in winter, reducing the lateral stems. Associated with winter pruning, the most vigorous stems are also selected and excess is eliminated (Tullio \& Ayub, 2013).

In search of improvements and solutions to crop impediments, several authors such as Tullio \& Ayub (2013), Antunes et al. (2014), Marchi et al. (2015), and Lugaresi et al. (2018), have studied variations in the pruning system, seeking to find ideal combinations for good production and fruit quality in winter pruning. However, this study has not yet been carried out in the western region of Paraná, which presents distinct climatic conditions. For the improvement of the production system it is of fundamental importance to know the vegetative and productive behavior of the blackberry for each producing region. In this context, this work aimed to evaluate the influence of pruning intensity on the phenology and production of blackberry 'Xavante' in the region of Palotina, PR, Brazil.

\section{Materials and Methods}

The experiment was conducted in the experimental orchard of the Federal University of Paraná, Palotina, PR,
Brazil, located at the geographical coordinates: 240 17' 02" $\mathrm{S}$ and 530 50' 24" W. The region has an average altitude of $333 \mathrm{~m}$, with a humid subtropical climate and an average temperature of $20.8^{\circ} \mathrm{C}$, according to the Köppen classification (IAPAR, 2018), average annual rainfall of 1,508 $\mathrm{mm}$ and soil type Red Eutroferric Latosol (IBGE, 2018).

The blackberry 'Xavante' seedlings, from Embrapa Clima Temperado, in Pelotas, RS, were planted in August 2016 with spacing of $0.50 \mathrm{~m}$ per plant and $1.5 \mathrm{~m}$ between rows, conducted in espalier system with double wire. Drip irrigation was used and weed management was done manually, and the other cultural treatments were performed according to the recommendations of Embrapa Temperate Climate for the crop (Antunes \& Raseira, 2004).

The experimental design was entirely randomized, with four treatments and seven repetitions. The treatments were made up as to the number of 1-m-long stems left per plant, corresponding to the height of the first strand: $2,4,6$, and 8 stems per plant, with each plot consisting of one plant. Winter pruning was performed on August 17, 2018. Two stems were also randomly selected per experimental plot, on which the evaluations were performed.

Evaluations were performed weekly, starting on September 13, quantified: evolution of sprouting and flowering (\%), in which the number of sprouts and the number of flowers emitted in the selected stems were counted over time. The total number of buds, open flowers, and fruits per plant by the end of the crop cycle were also quantified.

At the beginning of ripening, 5 fruits per plot were collected and taken to the Physiology and Plant Nutrition Laboratory of the Universidade Federal do Paraná, Palotina, Brazil, for physical-chemical analysis. Initially, the number of fruits per plant was counted in the field. Then, in the laboratory, the 5 fruits were weighed using precision scales, obtaining the average mass of the fruits. Based on this data and on the number of fruits per plant, it was possible to calculate the estimated productivity $\left(\mathrm{kg} \mathrm{ha}^{-1}\right)$ according to the density of the orchard. The diameter of the fruit was determined using a digital pachymeter. Soluble solids (SS) and titratable acidity (TA) were also evaluated. To determine the SS, the fruits were crushed with mortar and pestle, and the juice was evaluated in a bench top digital refractometer (HI96801, Hanna), and the result was expressed in ${ }^{\circ}$ Brix. To determine the acidity content, approximately $5 \mathrm{~g}$ of the must, obtained by crushing the blackberries, was used and the volume of $50 \mathrm{~mL}$ was completed with distilled water, 2 drops of phenolphthalein was added and titration was performed with standardized $\mathrm{NaOH} 0.097 \mathrm{M}$, the result being expressed in \% of citric acid (Adolfo Lutz Institute, 2008). The ripeness index (SS/AT or ratio) was then determined.

The results obtained were subjected to the analysis of variance, and when significant, were subjected to the regression test, and the means were compared by Tukey's test at 5\% probability, using the SISVAR software (Ferreira, 2014). 


\section{Results and Discussion}

Throughout the sprouting of the plants (Figure 1), it was observed that the plants pruned with 2 and 4 stems started sprouting earlier, and at 65 days after pruning, in mid-October, they had already reached $100 \%$ of their cumulative sprouting. In contrast, plants where pruning was done with 8 stems took more days to start budding and about 95 days to reach their maximum budding percentage on November 15, 2018.

The early sprouting in the treatments with 2 and 4 stems per plant, may be due to the stress to which the plants were subjected because of intense pruning, accelerating the release of new shoots to recover from the practice. In other words, plants submitted to more intense pruning resulted in less apical dominance, due to the removal of a larger number of buds, stimulating the emission of new shoots earlier (Vieira Júnior \& Melo, 2021).

It is important to point out that during the period this study was conducted, the weather conditions were atypical in the region (Figure 2), with a late winter, which occurred after pruning, in the month of August. The average expected temperature for the month of July is $17.8^{\circ} \mathrm{C}$, however in the year 2018 it was around $19.5^{\circ}$ and started to drop in the month of August, in which the average expected temperature is $19.8^{\circ} \mathrm{C}$, but was well below the expected, around $17.4^{\circ} \mathrm{C}$ (C. Vale, 2021).
This lower temperature in August influenced the beginning of sprouting and flowering, as found by Segantini et al. (2014), resulting in a lower percentage of sprouting when pruning was performed simultaneously with a period of lower temperatures.

Regarding the evolution of flowering (Figure 3), it is considered that the variations in temperature impaired the flowering of the plants. The amount of cold hours obtained in the year 2018 were not enough to meet the requirements of the blackberry 'Xavante', which needs 200 to 300 cold hours for the resumption of its development (Brugnara, 2016). In the year of the study, only 104 cold hours were obtained (Epagri, 2021). Lin \& Agehara (2021) state that temperature affects plant differentiation and flower induction, and can influence flowering uniformity, as occurred.

It can be seen in Figure 3, that the plants started flowering around October 5 , totaling 45 days after pruning. In a paper by Martins et al. (2019), studying phenology and thermal demand of blackberry cv. Tupy, in Dourados, MS, Brazil, they observed plants in full bloom stage at 40 to 50 days after pruning, evidencing the delay in flowering of blackberry in the present study, and they took more than 100 days to accumulate their full bloom $(100 \%)$, regardless of the treatment. This prolongation of the flowering period was associated with insufficient cooling, in which the number of cold hours accumulated until pruning was not enough for the

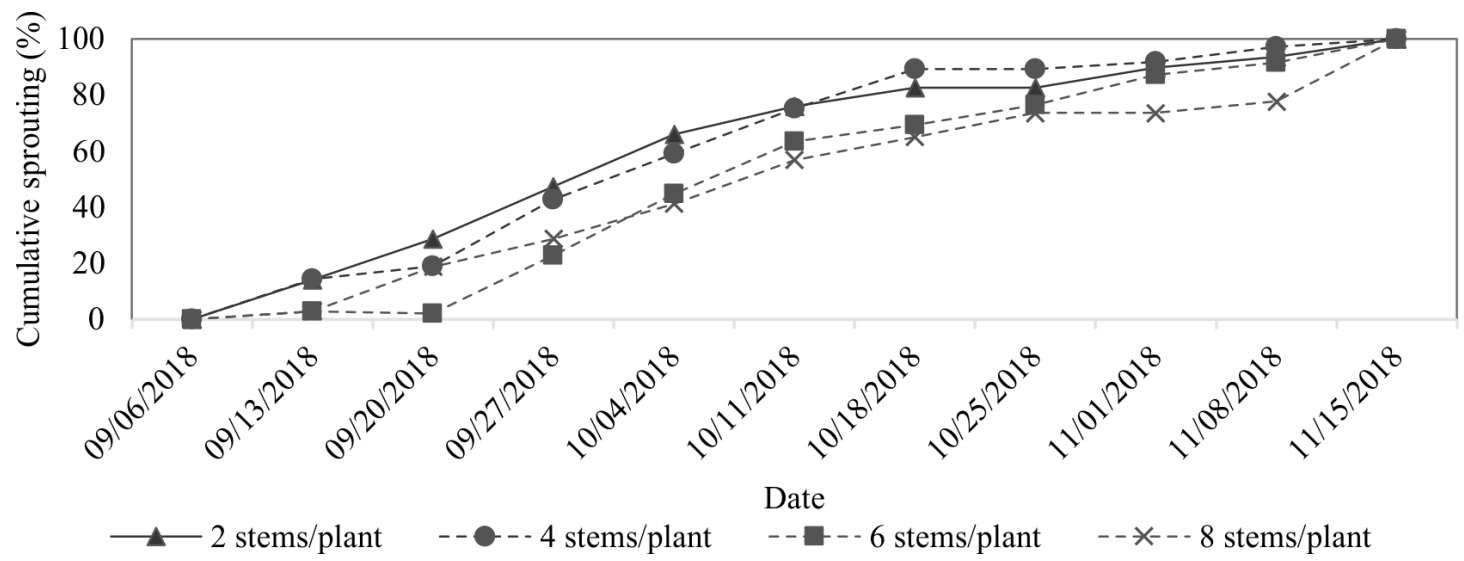

Figure 1. Cumulative sprouting percentage distribution of blackberry cv. Xavante submitted to different pruning intensities.

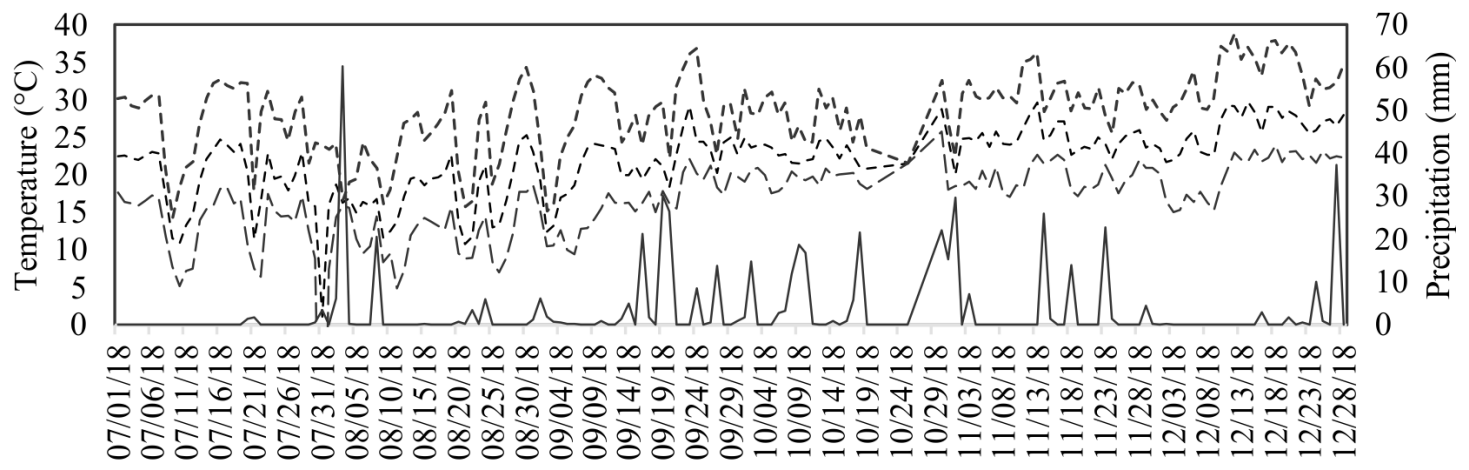

----- Average ----Minimum ----- Maximum _ Precipitation

Source: C. Vale (2021).

Figure 2. Average, minimum and maximum temperature and daily precipitation during the study conduct period (July to December 2018). 


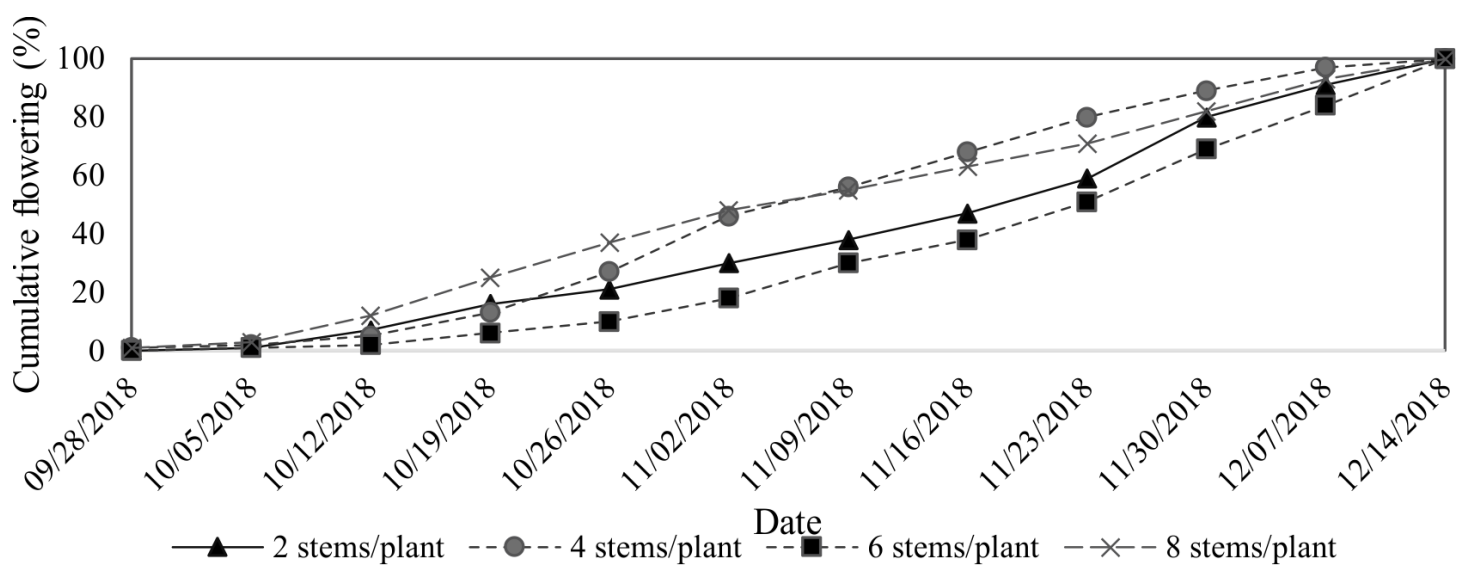

Figure 3. Cumulative flowering percentage distribution of blackberry cv. Xavante submitted to different pruning intensities.

plants to accumulate reserves for the reproductive stages (Segantini et al., 2014). In addition to prolonging the flowering period, insufficient cooling also resulted in the occurrence of different phenological stages simultaneously on the same plant in which the plants had an indeterminate flowering cycle, and consequently uneven fruit ripening.

For the number of shoots and flowers per plant (Table 1), plants kept with 6 stems showed fewer shoots per plant compared to the other treatments. For the number of flowers, the plants with 8 stems were found to be superior to the others. It can be seen that the greater number of shoots does not guarantee greater fruiting, in response to the vegetative and reproductive balance.

Regarding the number of fruits per plant (Table 2), it was observed that the treatment with 8 stems per plant was the most satisfactory, considering that these did not lose in mass. More intense pruning can result in lower productivity, due to the reduction of floral buds (Calai et al., 2020), however, for all treatments, the number of fruits per plant was relatively low when compared to other studies, such as Broetto et al.

Table 1. Number of shoots and flowers per plant of blackberry cv. Xavante submitted to different pruning intensities.

\begin{tabular}{ccc}
\hline $\begin{array}{c}\text { Treatments } \\
\text { (number of stems) }\end{array}$ & $\begin{array}{c}\text { Number of shoots } \\
\text { per plant }\end{array}$ & $\begin{array}{c}\text { Number of flowers } \\
\text { per plant }\end{array}$ \\
\hline 2 & $10.6 \mathrm{a}$ & $33.1 \mathrm{~b}$ \\
4 & $9.1 \mathrm{a}$ & $46.0 \mathrm{~b}$ \\
6 & $3.4 \mathrm{~b}$ & $32.3 \mathrm{~b}$ \\
8 & $7.7 \mathrm{a}$ & $68.1 \mathrm{a}$ \\
$\mathrm{CV}(\%)$ & 34.06 & 35.29 \\
\hline
\end{tabular}

Averages followed by equal letters in the columns do not differ statistically by the Tukey test at $5 \%$ probability.
(2009) and Marchi et al. (2015). This may have occurred due to atypical conditions during the execution of the work, in which the plants took about 45 days after pruning to start flowering, when, during this period, the days were already hot, so it was necessary to use irrigation, which resulted in plants with high vegetative vigor, and consequent reduction of the productive period. According to Segantini et al. (2014), temperature oscillations during this period can cause the plant to remain dormant for a longer period or the occurrence of unequal sprouting and flowering, directly interfering with plant productivity, as occurred.

As for the fresh mass of the fruits (Table 2), an important characteristic for their marketing in natura (Ferreira et al., 2016), only the treatment with 4 stems differed from the others, with the lowest mass, however the results found in this work, are similar to those reported by Marchi et al. (2015), in Guarapuava, PR, Brazil, in which they evaluated the time and intensity of pruning in the development of blackberry cv. Xavante, and obtained an average fruit mass of $4.1 \mathrm{~g}$ in the 2010/201 harvest. Regarding fruit diameter, there was statistical difference between the treatments with 2 and 4 stems, being observed in the first treatment the largest fruit diameter, due to the low production. Marcelis (1992) states that fruit growth is regulated by the availability of assimilates and the proportional distribution of these between the fruit and the other plant organs. In other words, the lower fruit load of the 2-stem treatment resulted in more assimilates being distributed to these organs.

The estimated yield was also influenced by pruning intensity. For this variable, the treatment with 8 stems stood out with the highest yield, statistically different from the other

Table 2. Average number of fruits per plant, mass and diameter of the fruits and productivity of blackberry cv. Xavante submitted to different pruning intensities.

\begin{tabular}{ccccc}
\hline $\begin{array}{c}\text { Treatments } \\
\text { (number of stems) }\end{array}$ & $\begin{array}{c}\text { Number of fruits } \\
\text { per plant }\end{array}$ & $\begin{array}{c}\text { Fresh fruit } \\
\text { mass (g) }\end{array}$ & $\begin{array}{c}\text { Fruit diameter } \\
(\mathbf{m m})\end{array}$ & $\begin{array}{c}\text { Estimated productivity } \\
(\mathbf{k g ~ h a})\end{array}$ \\
\hline 2 & $29.0 \mathrm{~b}$ & $4.37 \mathrm{a}$ & $22.8 \mathrm{a}$ & $1695.46 \mathrm{~b}$ \\
4 & $45.7 \mathrm{a}$ & $3.24 \mathrm{~b}$ & $20.3 \mathrm{~b}$ & $1997.13 \mathrm{~b}$ \\
6 & $29.7 \mathrm{~b}$ & $4.53 \mathrm{a}$ & $21.2 \mathrm{ab}$ & $1805.14 \mathrm{~b}$ \\
CV (\%) & $52.9 \mathrm{a}$ & $4.54 \mathrm{a}$ & $21.8 \mathrm{ab}$ & $3168.38 \mathrm{a}$ \\
\hline
\end{tabular}

Averages followed by equal letters in the columns do not differ statistically by the Tukey test at $5 \%$ probability. 
Table 3. Chemical quality of blackberry cv. Xavante fruits submitted to different pruning intensities.

\begin{tabular}{cccc}
\hline $\begin{array}{c}\text { Treatment (number of stems } \\
\text { per plant) }\end{array}$ & $\begin{array}{c}\text { Soluble solids } \\
\text { (Brix) }\end{array}$ & $\begin{array}{c}\text { Titratable acidity } \\
\text { (\%) }\end{array}$ & $\begin{array}{c}\text { Maturation } \\
\text { index }\end{array}$ \\
\hline 2 & $12.0 \mathrm{a}$ & $0.59 \mathrm{~b}$ & $20.5 \mathrm{a}$ \\
4 & $11.3 \mathrm{ab}$ & $0.77 \mathrm{a}$ & $15.2 \mathrm{~b}$ \\
6 & $10.2 \mathrm{bc}$ & $0.66 \mathrm{ab}$ & $15.5 \mathrm{~b}$ \\
8 & $9.9 \mathrm{c}$ & $0.8 \mathrm{a}$ & $13.0 \mathrm{~b}$ \\
CV (\%) & 7.94 & 14.45 & 19.67 \\
\hline
\end{tabular}

Averages followed by equal letters in the columns do not differ statistically, using Tukey's test at $5 \%$ probability.

treatments. That is, by performing more intense pruning, the number of buds of the plant is reduced and consequently their photosynthetic area, impairing the production and storage of photoassimilates for the normal development of fruit, compromising production (Ferreira et al., 2016).

When it comes to the chemical quality of the fruits (Table 3 ), the treatment with 2 stems per plant resulted in fruits with higher SS and lower TA, and the treatment with 8 stems, in fruits with lower SS and higher TA. A reduction in SS is observed as the amount of stems left during pruning increases, as a function of the existing source-drain relationship, in that the plants submitted to the treatment with 8 stems per plant, which had a higher production (considering that these did not lose mass and diameter) the amount of carbohydrate reserve translocated to each fruit, was lower. For this variable, there was a statistical difference between the treatments with 2, 6, and 8 stems per plant, where 2 stems per plant was superior to the others. These results corroborate the work of Marcelis (1992), who states that an increase in fruit number decreases the fraction for each generative drain considered individually.

As for TA, there was also a difference only between the treatments with 2 and 8 stems, with the treatment with 2 stems resulting in fruit with lower TA and the treatment with 8 stems higher $\mathrm{TA}$, the citric acid mainly influences sensory properties, influencing the taste and odor of the fruit (Hirsch et al., 2012). As for the maturity index, only the treatment with 2 stems per plant differed statistically from the other treatments.

According to Brugnara (2016), the higher this ratio the better the flavor, thus the higher value observed, of 20.5 for the treatment with 2 stems per plant indicates that these fruits, presented superior quality, because of their high maturity index.

It is important to note that for all treatments, the SS values obtained were above that reported by Lugaresi et al. (2020) and Guedes et al. (2013) who found values around $8{ }^{\circ} \mathrm{Brix}$, for $\mathrm{cv}$. Xavante, thus conferring a sweeter taste to the fruits obtained in this work, due to the low overall production. In addition to this low yield, Ali et al. (2011) state that variations in the content of chemical compounds may occur in response to the growing location due to differences in solar radiation intensity and temperature ranges that influence the organoleptic characteristics of the fruit.

When it comes to plant phenology and fruit quality, leaving 2 to 4 stems per plant results in a more uniform production cycle and fruit with a higher SS content, ideal for fruit intended for in natura consumption. However, when it comes to better productivity, the quantity of 8 stems per plant is considered ideal.

\section{Conclusions}

For the climatic conditions of Palotina, PR, Brazil, the intensity of pruning influences the phenology of blackberry 'Xavante', as well as the physical and chemical characteristics of the fruits.

More intense pruning management, keeping 2 and 4 stems per plant, results in more uniform vegetative development, greater production precocity, and fruit with better chemical quality. However, less intense pruning, keeping 8 stems per plant, results in higher yields.

\section{Acknowledgments}

We thank the Cooperativa Agroindustrial C. Vale, for providing the climatic data, which contributed to the discussion of the results of this study.

\section{Compliance with Ethical Standards}

Author contributions: Conceptualization: AJS; Data curation: LTMR; Formal analysis: MTHiguchi; Investigation: ACA; Methodology: AJS; Project Administration: ACA; Resources: AJS; Supervision: AJS; Validation: LTMR; Visualization: ACA; Writing - original draft: ACA; Writing review e editing: AJS.

Conflict of interest: There is no conflict of interest.

Financing source: This work did not receive financial support.

\section{Literature Cited}

Ali, L.; Svensson, B.; Alsanius, B. W.; Olsson, M. E. Late season harvest and storage of Rubus berries-Major antioxidant and sugar levels. Scientia Horticulturae, v. 129, n. 3, p. 376-381, 2011. https://doi. org/10.1016/j.scienta.2011.03.047.

Antunes, L. E. C.; Pereira, I. S.; Picolotto, L.; Vignolo, G. K.; Gonçalves M. A. Produção de amoreira-preta no Brasil. Revista Brasileira de Fruticultura, v. 36, n. 1, p.100-111, 2014. https://doi. org/10.1590/0100-2945-450/13.

Antunes, L. E. C.; Raseira, M. C. B. Aspectos Técnicos da Cultura da Amora-preta. Pelotas: Embrapa Clima Temperado, 2004. 54p. (Embrapa Clima Temperado. Documentos, 122). https:// www.infoteca.cnptia.embrapa.br/bitstream/doc/744812/1/ documento122.pdf. 13 May. 2021. 
Broetto, D.; Botelho, R. V.; Pavanello, A. P.; Santos, R. P. Cultivo orgânico de amora-preta cv. Xavante em Guarapuava PR. Revista Brasileira de Agroecologia, v. 4, n. 2, p.2208-2212, 2009. http://revistas.aba-agroecologia.org.br/index.php/cad/ article/view/4158/3182. 01 May. 2021.

Brugnara, E. C. Produção, época de colheita e qualidade de cinco variedades de amoreira-preta em Chapecó, SC. Agropecuária Catarinense, Florianópolis, v.29, n. 3, p.71-75, set./dez., 2016. https://publicacoes.epagri.sc.gov.br/RAC/article/view/151. 16 Jun. 2021.

Calai, F. A.; Radons, S. Z.; Dutra, B. Da R.; Betemps, D. L. Produção e qualidade de frutos de amoreira-preta submetida a diferentes intensidades de podas. In: Silva-Matos, R.R.S.; Oliveira, A.R.F.; Cordeiro, K.V. (Eds.). Desafios e sustentabilidade no manejo de plantas 2. Ponta Grossa: Atena Editora, 2020. p.42-49. https:// doi.org/10.22533/at.ed.7112027054.

Cooperativa Agroindustrial - C. Vale. Previsão do tempo. https:// www.cvale.com.br/site. 22 Jun. 2021.

Croge, C. P.; Cuquel, F. L.; Biasi, L. A.; Bona, C. M. de. Performance of blackberry cultivars in Cerro Azul - PR. Revista Brasileira de Fruticultura, v. 38, n. 3, e141, 2016. https://doi.org/10.1590/010029452016141.

Empresa de Pesquisa Agropecuária e Extensão Rural de Santa Catarina - Epagri. Centro de Informações de Recursos Ambientais e de Hidrometeorologia de Santa Catarina - Ciram. Índices agrometeorológicos 2021. https://ciram.epagri.sc.gov.br/ agroconnect/. 23 Jun. 2021.

Ferreira, D. F. Sisvar: a guide for its bootstrap procedures in multiple comparisons. Ciência e Agrotecnologia, v.38, n.2, p.109-112, 2014. https://doi.org/10.1590/S1413-70542014000200001.

Ferreira, L. V.; Picolotto, L.; Cocco, C.; Finkenauer, D.; Antunes, L. E. C. Produção de amoreira-preta sob diferentes sistemas de condução. Ciência Rural, v. 46, n. 3, p.424-426, 2016. https://doi. org/10.1590/0103-8478cr20140601.

Figueiredo, M. A.; Pio, R.; Silva, T. C.; Nascimento Silva, K. Características florais e carpométricas e germinação in vitro de grãos de pólen de cultivares de amoreira-preta. Pesquisa Agropecuária Brasileira, v. 48, n. 7, p.731-740, 2013. https://doi. org/10.1590/s0100-204×2013000700005.

Guedes, M. N. S.; Abreu, C. M. P. de; M., L. A. C.; Pio, R.; Abreu, J. R. De; Oliveira, J. O. de. Chemical characterization and mineral levels in the fruits of blackberry cultivars grown in a tropical climate at an elevation. Acta Scientiarum. Agronomy, v. 35, n. 2, p. 191-196, 26 mar. 2013. https://doi.org/10.4025/actasciagron. v35i2.16630.

Hirsch, G. E.; Facco, E. M. P.; Rodrigues, D. B.; Vizzotto, M.; Emanuelli, T. Caracterização físico-química de variedades de amora-preta da região sul do Brasil. Ciência Rural, v.42, n.5, p.942-947, 2012. https://doi.org/10.1590/S0103-84782012005000021.

Instituto Adolfo Lutz. Procedimentos e determinações gerais. Métodos físico-químicos para análise de alimentos. 4.ed. São Paulo: Instituto Adolfo Lutz, 2008. p. 85-104. http:// www.ial.sp.gov.br/resources/editorinplace/ial/2016_3_19/ analisedealimentosial_2008.pdf. 22 Jun. 2021.
Instituto Agronômico do Paraná - IAPAR. Cartas climáticas do Paraná - 2018. http://www.iapar.br/modules/conteudo/conteudo. php?conteudo=863. 14 Oct. 2018.

Instituto Brasileiro de Geografia e Estatistica - IBGE. Mapas temáticos 2018. https://mapas.ibge.gov.br/tematicos/solos.html. 14 Oct. 2018.

Lin, S.; Agehara, S. Foliar application of defoliants before winter chill accumulation advances budbreak and improves fruit earliness of blackberry under Subtropical Climatic Conditions. Hortscience, v. 56, n. 2, p. 210-216, 2021. https://doi.org/10.21273/ hortsci15533-20.

Lugaresi, A.; Giacobbo, C. L.; Uberti, A.; Prado, J.; Girardi, G. C.; Lovatto, M.; Fischer, L. O. Influence of cultivar and pruning management on the phenological aspects of blackberry. Scientific Electronic Archives, v. 13 , n. 5, p. 27-32, 2020. https://doi. org/10.36560/1352020995.

Lugaresi, A.; Uberti, A.; Giacobbo, C. L.; Lovatto, M.; Girardi, G. C.; Wagner Junior, A. Management of pruning and evaluation in blackberry cultivars in relation to productive characteristics and bioactive compounds. Anais da Academia Brasileira de Ciências, v. 90 , n. 4 , p. $3879-3885$, 2018. https://doi.org/10.1590/00013765201820180456.

Marcelis, L. F. M. The Dynamics of growth and dry matter distribution in cucumber. Annals of Botany, v. 69, n. 6, p. 487-492, 1992. https://doi.org/10.1093/oxfordjournals.aob.a088376.

Marchi, T.; Broetto, D.; Sato, A. J.; Maia, A. J.; Botelho, R. V.; Verlindo, A. Época e intensidade de poda no desenvolvimento e produção de amoreira-preta cv. Xavante cultivada em sistema orgânico. Comunicata Scientiae, v. 6, n. 3, p.326-326, 2015. https://doi.org/10.14295/cs.v6i3.670.

Martins, W. A.; Santos, S. C.; Jara, R. S.; Souza, J. L. A. C. de; Galvão, J. R.; Biscaro, G. A. Fenologia e demanda térmica de amoreirapreta cv. Tupy. Revista de Ciências Agrárias, v. 42, n. 3, p. 720-730, 2019. https://doi.org/10.19084/rca.17529.

Segantini, D. M.; Leonel, S.; Cunha, A. R.; Ferraz, R. A.; Ripardo, A. K. S. Exigência térmica e produtividade da amoreira-preta em função das épocas de poda. Revista Brasileira de Fruticultura, v.36, n.3, 568- 575, 2014. https://doi.org/10.1590/0100-2945-295/13.

Strik, B. C. Pruning and training systems impact yield and cold hardiness of 'Marion'trailing blackberry. Agriculture, v. 8, n. 9, p. 134, 2018. https://www.mdpi.com/2077-0472/8/9/134. 25 Mar. 2021.

Tullio, L.; Ayub, R. A. Produção da amora-preta cv Tupy, em função da intensidade da poda. Semina: Ciências Agrárias, v. 34, n. 3, p.1147-1152, 2013. https://doi.org/10.5433/1679$0359.2013 v 34 n 3 p 1147$.

Vieira Júnior, H. C.; Melo, B. Poda das fruteiras. http://www. fruticultura.iciag.ufu.br/poda.html. 16 Jun. 2021.

Vignolo, G. K.; Picolotto, L.; Gonçalves, M. A.; Pereira, I. dos S.; Antunes, L. E. C. Presença de folhas no enraizamento de estacas de amoreira-preta. Ciência Rural, v. 44, n. 3, p. 467-472, 2014. https://doi.org/10.1590/s0103-84782014000300013. 